\title{
Harrison Birtwistle's “Orpheus-Project”: Images of Melancholy
}

\author{
T. V. Tsaregradskaya
}

Gnesins' Russian Academy of Music, 30-36, Povarskaya str., Moscow, 121069, Russian Federation

For citation: Tsaregradskaya, Tatiana. "Harrison Birtwistle's 'Orpheus-Project': Images of Melancholy". Vestnik of Saint Petersburg University. Arts 9, no. 2 (2019): 256-279.

https://doi.org/10.21638/spbu15.2019.203

British composer Harrison Birtwistle (b. 1934) is considered to be one of the most striking figures of contemporary classical music. The most important idea which crosses many of his pieces is the multiple embodiment of the Orpheus myth. Orpheus is interpreted not only as a person with his own tragedy, but also becomes an umbrella phenomenon embracing his mythic brother Linos, his wife Euridice, and different aspects of the voyage to the Underworld: wandering in the kingdom of Hades, conducting a dialog with the King of the Dead, as well as various-level reflections on the whole myth (allegoric, metaphoric, symbolic). Embodying all these aspects, the composer takes a wide range of texts (from Ausonius and Boethius, to Christopher Logue and Sir Thomas Wyatt, to Rainer Maria Rilke and Peter Zinoviev) and produces a number of works of different genres: instrumental pieces (Linoi), cantatas (The Death of Orpheus, Meridian), choral compositions (Fields of Sorrow, On the Threshold of the Night), operas (The Mask of Orpheus, The Corridor), and song cycles (Orpheus Elegies). Thus, Birtwistle's reflections on Orpheus form a series of works that display the whole range of images and situations contained in the myth, taken from different angles that can be compared to Picasso's famous series of reinterpretations of Las Meninas. One feature common to all these compositions is:that they are emotionally charged with a deep melancholy characteristic of a composer who recognizes in himself this kind of temperament as his peculiarity, and inspired by his famous predecessor, Dürer and Dowland.

Keywords: Harrison Birtwistle, Orpheus myth, series of works, Zinoviev, Rilke, Ausonius, Boethius, melancholy as an emotional modus.

\section{Orpheus has, of course, been a bit of an obsession for me [1, p. 10]. \\ H. Birtwistle}

Harrison Birtwistle (b. 1934) is one of the most acknowledged contemporary composers in Great Britain. In the overall "spiritual landscape" he occupies his own special place: he escapes any aesthetic declarations, tries not to join any position considering new compositional techniques, denies discussing his artistic aspirations, and avoids explaining his work. That he maintains a personal distance paradoxically does not discourage various critics from discussing his compositions and maintains public interest. The result is obvious: today we have five monographs describing Harrison Birtwistle's work [2-6], and musicologists tend to evaluate his compositions as "arguably the most exciting, original and challenging music ever to have been produced by a British composer" [4, p. ix].

(c) Санкт-Петербургский государственный университет, 2019 
Birtwistle began to study music as a clarinet performer, and only after entering the Royal Manchester College of Music did he start to compose. During his schoolyears he communicated to members of so-called Manchester School of post-war British composers (among them Alexander Goehr, Peter Maxwell Davies, and famous pianist John Ogdon). British music history considers this society to be a promoter of avant-garde ideas in European music, mainly the work of Second Vienna school composers. Birtwistle, mostly with the help of Alexander Goehr, explored everything around the Second Vienna School but refused the radicalism of the Darmstadt School and avoided the most radical means of composition, techniques of total serialism. By this he separated himself from the explicit avant-garde connections and concentrated not in the domain of composition techniques, but searched mostly in the sphere of artistic ideas, demonstrating profound interest for mythology and different strategies of musical form-building. Such a position did not lead the composer to traditionalism, but instead it exposed him to different influences without trapping him in any doctrine and helped him avoid eclecticism.

The sphere of his artistic interests is wide and not limited to purely musical phenomena. The most powerful inspiration comes to Birtwistle from painting: the composer himself agrees about the strong influence of such painters as Piero della Francesca, Pieter Breugel, Jan Vermeer, Albrecht Dürer, Paul Cézanne, Pablo Picasso, and Roger Bacon. The most fundamental of these was the influence of Paul Klee; many compositions started from impulses from this artist ${ }^{1}$.

Another important source of ideas was literature, poetry, and drama; among the inspirations we find Sappho, Ovid, Ausonius, Boethius, and Japanese poetry as well as early English authors. From the very beginning ,Birtwistle developed a great interest in Greek tragedy, William Blake's verses, William Shakespeare's dramas; contemporary poets such as Paul Celan, Lorine Niedecker, and Rainer Maria Rilke form the circle of favorites beginning from the 1980s. His "musical mentors" can be separated into two groups: early music is represented by Guillaume de Machault, Johannes Ockeghem, Heinrich Isaak, John Dowland, Giovanni Gabrieli, and J. S. Bach; contemporary music is represented by Eric Satie, Igor Stravinsky, Olivier Messiaen, Morton Feldman, and Edgar Varèse.

Nature is also among sources of inspiration: the composer was born in the north of England, Lancashire, and northern landscapes were dear to him; he spent a couple of years in Scotland on the island of Raasay, and some pieces keep the atmosphere of this territory.

But the most powerful source was mythology, Greek as well as English, and in this domain the myth on Orpheus was central. Among the works exploring this theme we find three key pieces where Orpheus's name is used explicitly: this includes a small cantata "Nenia: the death of Orpheus" (1970), a large-scale opera "The Mask of Orpheus" (1973-1986), and the chamber composition "26 Orpheus Elegies on the texts by Rilke" (2003-2004) for countertenor, oboe, and harp. English scholar J. Cross also noted some musical pieces which form a sort of periphery of a myth: such choral pieces as "Meridian" (1970-1971), "The fields of sorrow" (1971), "On the threshold of the night" (1980), and the chamber opera "The Corridor" (2008-2009) indirectly but clearly point at Orpheus (or the composer makes necessary accents in the text). Other compositions may not have a

1 These are the most well-known pieces written after famous paintings: The Triumph of Time after Breugel; Melencolia after Dürer's etching; Carmen Arcadia Mechanicae Perpetuum after "Twittering machine" by Paul Klee; the opera "The Minotaur" in inspired by a series of drawings by Picasso, "The Tauromachia." 
straightforward relationship to the Orpheus story but share some important ideas and are thus influenced by it: the author himself explained that the opera "Minotaur" (2008) has connections with the Orpheus theme. Orpheus became a "spinal cord" for the composer's work, the starting point for a whole set of motives constituting the myth. For understanding of the composer's worldview, we need to explore the configuration of this "Orpheus project," the history of its consecutive structuring, and central ideas and peripheral details. It is also important to reveal the whole complex of ideas which Birtwistle embodied in his works, the specificity of the interpretation of the Orpheus history.

For $20^{\text {th }}$ century art Orpheus became no less attractive than for other epochs. The Orpheus myth seems to be a magnet for many painters and poets of the $20^{\text {th }}$ century ${ }^{2}$, but musicians apparently were more sensitive to the Orpheus history. Among the most outstanding work featuring Orpheus we find Darius Milhaud, "Le malheures d'Orphée"; Ernst Krenek, "Orpheus und Eurydike"; Paul Dessau, "Orpheus"; Alfredo Casella "La favola d'Orpheo"; Pierre Schaeffer and Pierre Henry "Orphée 51"; Lukas Foss "Orpheus”; Louis Andriessen “Orpheus," Philip Glass “Orphée”; Beat Furrer "Orpheus’ Bücher”; Olga Neuwirth "Euridyke" and many others. Of special importance is the ballet "Orpheus" by Igor Stravinsky, which became a model for such compositions as "The Mask of Time" by Michael Tippett and "Orpheus Behind the Wire" by Hans Werner Henze. Stravinsky's ballet was also of great significance for Birtwistle because the composer recognized Stravinsky as a crucial influence on his work.

\section{The way to Orpheus}

The first compositions by Harrison Birtwistle are not linked to Orpheus myth ${ }^{3}$. The seeds for the future are very uneven and if we start seeking the main interest of his compositional aspirations, we first find a steady interest in formal schemes. Birtwistle was eleven when he started to play clarinet, and in his interview with Dan Warburton, he insisted that the desire to compose arose at the same time: "When I was a kid, I wrote music. From the age of eleven until I went to Manchester at the age of eighteen" [7]. We have no evidence of his early compositions, but we know exactly that his first performed piece was "Refrains and choruses" for wind quintet $(1957)^{4}$. After this piece was selected for performance at the 1959 Cheltenham festival, the composer symbolically sold his clarinets (but this story is sometimes considered apocryphal). The performance was successful and the score was published in "Universal Edition," but as the composer's first biographer Michael Hall states, the professional path wasn't easy for Birtwistle: "It took seven years of trial and error" [5, p. 17]. And only in Tragoedia for flute, oboe, horn and two bassoons, two violins, viola, cello and harp (1965) "everything fitted into the place" [5, p. 17].

2 Some outstanding works include: Oscar Kokoschka, "Orpheus and Euridice"; Jean Cocteau, a trilogy of films on Orpheus; Rainer Maria Rilke, Sonnets to Orpheus; Paul Klee, "A garden for Orpheus"; Pablo Picasso, "The death of Orpheus"; Jean Anouilh, "Eurydice"; Tennessee Williams, "Orpheus Descending"; Guillaume Apollinaire, "Le Bestiaire ou Cortège d'Orphée”; Wystan Hugh Auden, "Orpheus".

3 Among the first compositions praised by critics were Refrains and Choruses for wind quintet (1957), "Monody for Corpus Christi for soprano, flute, horn and violin" (1959); "The World is discovered," six instrumental pieces for wind, harp and guitar after Heinrich Isaak (1961).

4 The end of the 1950s was an important period in the development of his own style, and one of the most crucial influences was Messiaen's, whose "Cinq rechants" (1948) had some features close to "Refrains and choruses." 
Tragoedia outlined one of the domains where Birtwistle found his inspiration until today: the domain of ancient Greek tragedy with its canonic structure, which has been attractive for dramaturgy and music for centuries. From this very moment the notion of "tragedy" both as structure and as content began to define the composer's approach. The structural idea, with its order of units (Prologue, Parodos, Episodion, Stasimon, Episodion, Exody) and symmetries, defines the form of Tragoedia ${ }^{5}$. Tragedy as structure and content became an important means for organizing Birtwistle's music.

Studies in Greek tragedy as structure include compositions written after the Tragoedia: Monodrama (1967) and Nomos (1967-1968). 1968 marks the first attempt to employ the details of the Orpheus myth. The first step in exploring the topic was the composition Linoi (1968) for clarinet and piano ${ }^{6}$. According to several sources, Linos was Orpheus' brother and also an outstanding musician (some myths describe him as Hercules' music teacher). But this wasn't the point of Birtwistle's interest. Linos died tragically, which is why his name became associated with the genre of a tragic (funeral) song (linoi) $)^{7}$. The details are in the text: the clarinet being an inheritance of ancient Greek aulos becomes the symbol of a funeral rite and the song he performs is the linoi (or ailinon ${ }^{8}$ ), ancient Greek genre of threnody, music of funeral rite in the author's version. Here for the first time Birtwistle uses specific long melodic lines of ambiguous character: it is continuous, but in the nearest perspective small cells are obvious, they are tightly interlocked and able to prolong melodic development for a long time. This first rather modest experience in building a threnody had long-lasting consequences. The first was "Nenia."

\section{"Nenia: The Death of Orpheus"9 (1970)}

The idea of this composition originated during Birtwistle's schoolteaching in the $1960 \mathrm{~s}^{10}$. The text for this dramatic scene (in a way a one-act opera) was written by a close friend of Birtwistle, Peter Zinoviev. Zinoviev, a son of Russian emigres and gifted poet and

${ }^{5}$ According to composer's notes, "the work is intended to bridge the gap between 'absolute music' and theatre music. It contains a specific drama, but this drama is purely musical. The title doesn't imply 'tragic' in the nineteenth century sense. 'Tragoedia' literally means 'goat-dance' and the work is concerned with the ritual and formal aspects of Greek tragedy rather than with the content of any specific play. This idea is present in the work on various levels. The instruments are divided into three groups: wind quintet, harp and string quartet. The cello and horn, being the 'odd men out' of their respective groups, act as individual opponents within the conflict, while the harp acts as a linking continuo. This instrumental organization is not a reference to Renaissance antiphony; it is simply a reflection on the level of instrumentation of the drama which is also expressed in the form of the work. The essence of the work structure is symmetry - more specifically bilateral symmetry in which concentric layers are grouped outward from a static central pillar [5, p. 173-4].

6 This piece later was orchestrated for clarinet, piano and electronics, and also for clarinet, piano, and cello.

7 Besides the version of assassination by Hercules, a myth of Apollo murdering Linos also exists.

8 The name "ailinon" appeared in the course of performing the song with its repeated exclamations: "Ai Linon", i. e. as a repeated name of Linos.

9 "Nenia: The Death of Orpheus", for soprano, 3 bass clarinets, crotales and piano (1970).

${ }^{10}$ In the beginning of the 60s Birtwistle worked at the Cranborne Chase School. M. Hall describes his stay in a following paragraph: "They (pupils. - T. T.) thought Birtwistle, with his taste for unusual contexts, would be intrigued that in Virgil's Georgics the episode is introduced to warn beekeepers that if they offended common decency their swarms could disappear" [5, p. 69]. The role of the bees is emphasized in the libretto of "The Mask of Orpheus". 
musician ${ }^{11}$, became the mediator between Birtwistle and his "Orpheus project." He wrote texts and comments on "Nenia" and the future opera "The Mask of Orpheus."

In this dramatic scene three actors take part: the narrator, Orpheus, and Eurydice, but all are performed by one female singer who has to use three different "styles" of singing for the necessary dramatic effect. The specifics of this scene are revealed in the fact that all three persons exist outside the dialog: the narrator is concentrating on retelling events, Orpheus exclaims the name of Eurydice, and Eurydice pronounces the name of Orpheus and tries to comfort him adding "my love." Such a situation can be imagined in the conditions of puppet theatre, with one actor who narrates and portrays different puppets with his own voice. This is just conjecture, but this is also a key method used in "The Mask of Orpheus"12.

The story contains the detailed description of events concerning the death of Orpheus. The narrator's tone is quite impassive and can be associated with Brechtian Verfremdung. Of special attention is the narrator as a personage of "epic theatre." His role can be compared with the choir in ancient Greek tragedy, because he presents not a personal view, but the collective consciousness with its impassiveness. The story told by the narrator is fixing the "state of affairs" at the moment when Orpheus is living his last days in the world of people. The author builds his narration in a tone of "ironic protocol": we see Orpheus maniacally fixated on the death of the beloved, weeping and exclaiming her name only. We also see women (maenads or Bacchus' servants) who attack Orpheus and kill him; we see the world after the death of Orpheus, which is the same as before (see: Appendix 1). In this narration, comments sometimes refer to some little -known events, such as the death of Eurydice from a snake bite, not only because she escapes the chase of Aristaeus the bee-keeper. The case of her death is not clear: it is not explained in the text, but some sources interpret it as a result of Apollo's punishment for adultery: Aristaeus not only chased the nymph for her benevolence, but he also succeeded and Orpheus did not know about this. This impassive tone is evident in the description of natural cataclysms at the moment of Orpheus' death: they are commented "as is customary." The mythological features play a role in every event: the happiness of love is balanced by tragic death - what is above is also underneath, as the law of the myth prescribes.

The structure of the composition points to a ritual component: the instrumentation was planned to resemble an antique burial ritual with an abundance of wind instruments. ("Nenia" incorporates three instruments with beautiful sound - three bass-clarinets, and the piano is determined to play the role of a pizzicato instrument as far as it is prepared with the help of erasers.) Three different manners are used in the characteristics of personages: the narrator uses Sprechgesang, and Orpheus and Eurydice sing in different styles: if Eurydice sings in a simple singing style of a Classical epoch (akin to Gluck), Orpheus uses mannerist singing with trills, tremolo, glissando, staccato, crescendo, and diminuendo on the same note, long vocalizing one note (probably as an allusion on early Barock Italian

11 Petr L'vovitch Zinoviev, aBritish engineer and inventor, was of Russian origin. He is famous for creating the company Electronic Music Studio, and developing a synthesizer VCS3 at the end of the 1960s. Zinoviev became the author of libretto to the "Mask of Orpheus" by Harrison Birtwistle, as well as the text to "Nenia: The Death of Orpheus" [9]. We should add that the role of Peter Zinoviev is crucial for the development of British rock-music. Such rock groups as Deep Purple and Pink Floyd acknowledged his influence.

12 It is possible to see in "Nenia" the methods of puppet theatre that Birtwistle used in his previous opera "Punch and Judy," using the basis of English puppet theatre. 


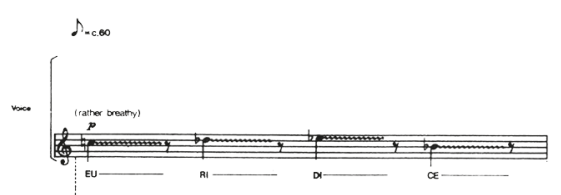

12

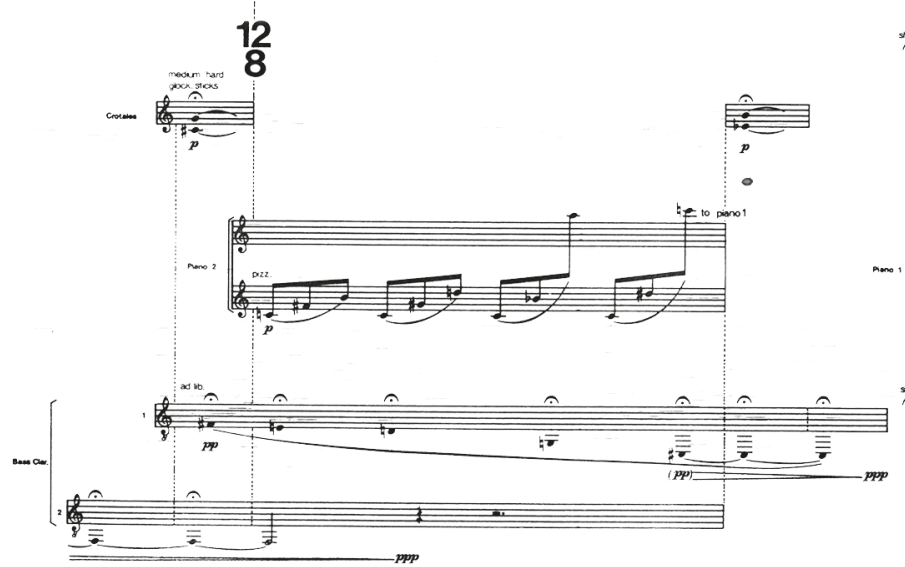

Ex. 1. Orpheus' singing. "Nenia: The Death of Orpheus" [I, p. 13]

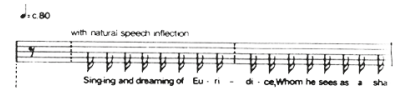

$\because$\begin{tabular}{cc}
1 & 4 \\
\hdashline & 8
\end{tabular}

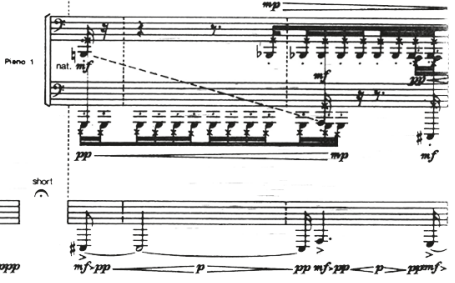

style, indicating Monteverdi's Orphee). All this should point to an outstanding mastery of old belcanto, with its flourishing abundance of singing techniques (ex. 1). Rapid change of vocal techniques can be associated with well-known Sequenza III for voice by Luciano Berio, where the number of vocal styles reaches its possible maximum. In the accompaniment, bass clarinets play long melancholic lines using crescendo and diminuendo (as if moaning). Their function is mostly to create a background for the "trio" of narrator, Orpheus, and Eurydice. Their presence reveals a ritualistic role: they are mimicking ancient Greek wind instruments, and their performance transmits the real time of the funeral ritual (ex. 2).

The emergence of $\mathrm{B}$ clarinet can be interpreted as the arrival of a new personage: the instrument becomes a substitute for Orpheus himself at the very moment of his death. The clarinet's line is close in its stylistic to free expression of Orpheus' singing, and the finale of this expression is evident when the narrator describes the cruel death of the hero: a nervous and ugly line reminds us of the brutality of bacchants as they "tore to pieces" the body of Orpheus. Euridice's singing at this moment is strangely triumphant: "Orpheus, my love, Orpheus" - her words give the impression of a fulfilled desire (ex. 3).

Comparing "Nenia" to the previous "Orpheus" opus, Linoi, we can easily observe their conceptual resemblance: at the basis lies a common model of the funeral ritual and its musical genres. Linoi is more modest, only with song itself and without words, while "Nenia" is a small play, a spectacle. But "Nenia" can be also interpreted as a draft of the "Mask of Orpheus," a "lyric tragedy," as Zinoviev called it. 
27
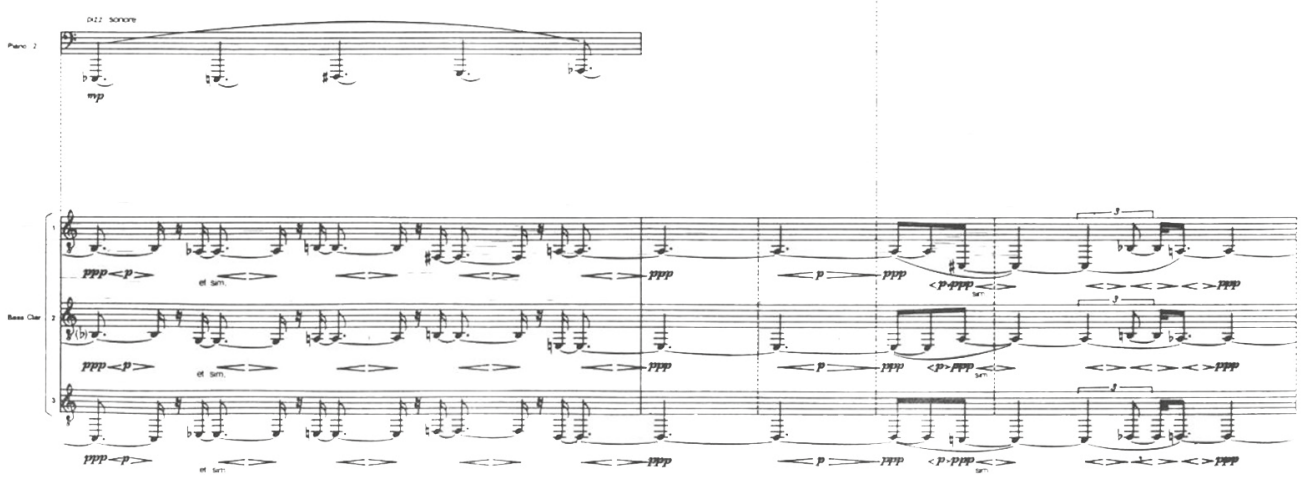

Ex. 2. Bass-clarinets. "Nenia: The Death of Orpheus" [I, p. 21]

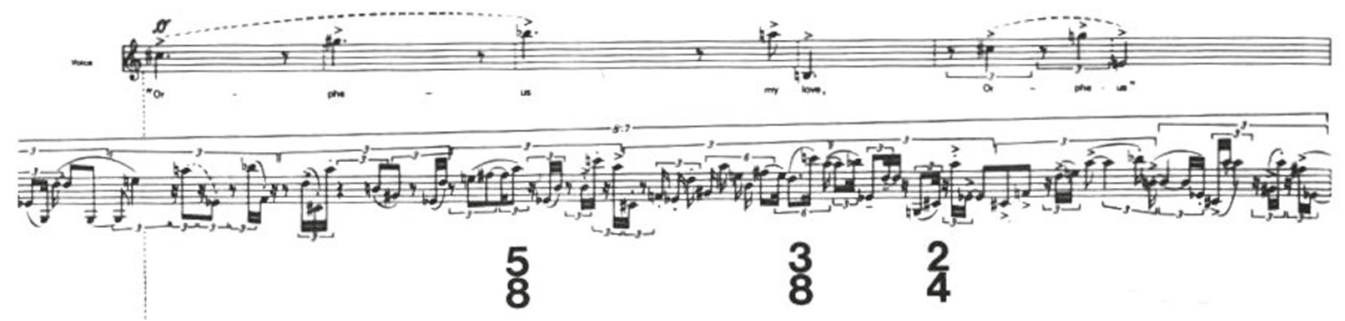

Ex. 3. Eurydice. "Nenia: The Death of Orpheus" [I, p. 32]

\section{“The Mask of Orpheus”, opera in three acts (1973-1986)}

"The Mask of Orpheus" is often considered the most daring and large-scale project from the composer's earlier work. Birtwistle's creation of this composition for music theatre is divided into two periods: 1973-1975, the time for completing first two acts, and 1986, the finalization of the project. The period of 1975-1983 was complicated for the composer: troubles arouse around the opera concerning changes in the libretto and finding another producer; and Birtwistle himself also was not able to work intensively because of his new duties as tehe musical director of Royal National Theatre at Glyndebourne. The year 1986 saw the completion of the opera and its premiere in May.

The vision of "The Mask of Orpheus" did not come as something definite and clear; on the contrary, everybody involved in the process recalled severe difficulties in shaping 
the idea. In 1970 the composer was thinking about an opera about Chronos and even devised a name: "Chronia." Closer to the end of 1971, a new subject became more attractive: "The death of doctor Faust,"a play by Michael de Ghelderode ${ }^{13}$. Peter Zinoviev even wrote a full text for libretto, but then everything turned again to the topic of Orpheus. In 1973 an opera on the subject of Orpheus was commissioned to Birtwistle and Zinoviev and work began.

There are many details concerning the ideas and twists and turns in the subject in the projects "Chronia" and "Orpheus."14 In the first phase, the opera was called simply "Orpheus." However, the ideas of both composer and librettist were rather radical. We can see this even in the course of a reduced libretto retelling:

Act 1 (Parados) ${ }^{15}$. Apollo teaches Orpheus to sing at the dawn. The sun raises and slowly lights up the landscape.

Scene 1 - presents Orpheus singing a song of reminiscence about his campaign with Argonauts. Then he falls in love with Eurydice ( $1^{\text {st }}$ Duet of Love). The signs of the future are pessimistic ( $1^{\text {st }}$ Passing Cloud).

Scene 2 - Eurydice's reminiscence. Her death is performed simultaneously by singers and by mimes. Aristaeus tries to seduce Euridice: in one version she resists his courtship, in another - she doesn't (she is raped). Escaping Aristaeus Eurydice is stung by a snake.

Scene 3 - presents a temporal shift. Orpheus (performed by a mime) witnesses Eurydice's death. Burial ceremony is the echo of wedding, they both resemble a ritual of sacrifice ${ }^{16}$. Orpheus goes to Oracle asking about the way to return Eurydice. The Oracle in turn demands from Orpheus his gift of magic singing. Orpheus anticipates the journey to the Underworld.

Act 2 begins with the second time shift where Orpheus again becomes the witness of Eurydice's death. Puppets, symbols of the myth, sing a love duet. The imaginary journey of Orpheus begins.

Scene 1 - the descent into the Underworld. Orpheus sees himself as Hades, Eurydice as Persephone and Oracle as Hecate.

Scene 2 presents the way back. But Orpheus discovers that everything happened to him in the Underworld was just a dream and he never visited the Underworld and he has lost Eurydice forever.

Scene 3. Orpheus commits suicide. His life as a hero is over.

\section{Act 3}

Scene 1 - one more time shift, rebirth of Orpheus as a mythological figure.

The further order of events becomes more and more complicated as far as it is managed by raising and falling Tides. This concept is explained by Zinoviev: "The concept of Tides is simple. A number of objects lie on a beach. The tide covers them as it rises and uncovers as it falls. Each successive high tide is higher than the last (as the moon is becoming fuller) and so some of the objects are not covered by one tide but are by the next. The objects themselves are not important $\langle\ldots\rangle$ but represent sequences of actions within the opera; $\langle\ldots\rangle$ as the tide rises and falls, so

13 Oddly enough during these years another famous composer took de Gelderode's play as a libretto for the opera: it was Gyorgy Ligeti and his "anti-anti-opera" Le Grand Macabre (1978).

14 A detailed research on this subject is performed by D. Beard in [3].

15 Misspelling.

16 As D. Beard comments: “The libretto's scheme recalls the sectional analysis of rituals by structural anthropologist such as Levi-Strauss" [3, p. 100]. 
are some of the same objects covered and uncovered and so dramatic sequences take place" [3, p. 114].

Scenes 2 and 3 respectively are designed as a chain of events which flash as pieces of visions or reflections: Eurydice's death, Orpheus's suicide, the death of Orpheus from a thunderbolt, the death of Orpheus from bacchants, Orpheus's scull becoming an Oracle and Apollo who orders him to silence.

Exodos - returns to the void analogical to the beginning. It represents a series of echoes which become more and more distant. The myth can restart.

This idea was a real challenge for the composer as well as the performers. It is not surprising that "Mask of Orpheus" impressed spectators with its concepts, but it was not successful in its production and became mostly a text for art critics' interpretations. Its spliced personages and, non-linear story produced comments on its postmodern esthetic. Truly enough, the crisis of the opera narrative is evident most of all in "The Mask," and here we find the ideas similar to Luciano Berio's operas (for example, "Un re in ascolto") with its intricate play of narratives. Omitting the details of grandiose conceptions designed by both composer and librettist, we won't discuss the idea of electronic music in opera, which was avant-garde idea for the period ${ }^{17}$, but we will try to concentrate on the main concepts:

- The history of Orpheus' life reflected in the myth is basic for the libretto. As far as Zinoviev shared the so-called Aristotelian view on Orpheus not as a particular person, but a symbolic figure accumulating features of different heroes and poets, he reflected in libretto the different versions of the Orpheus myth. As a result we find in libretto three personages - Orpheus, Eurydice, and Aristaeus - but each of them is presented in three forms: as a person (represented by a singer), as a hero (represented by a mime), and as a myth (represented by a puppet).

- Multiplicity of myth is reflected by non-linearity of the narrative: for example, Orpheus dies several times during the opera performance. It is impossible to retell coherently the plot of the opera. The Preface, written by Zinoviev for publication of libretto at the Universal Edition (see: Appendix 2), is characteristic for its essayistic non-narrative form. Even in its reduced form, libretto portrays not the sequence of events, but their ambivalence and ramification of different versions.

- Through non-linearity of the narrative, the idea of non-linear time is realized: Orpheus designated the Supreme Cause, Chronos or Time. There is some evidence that this was divided into three: "unending time," "manifested time," and "unborn time" [II].

The combination of music, singing, dramatic action, myth, mimic performance, dance, and electronics - pretty much everything was used to create a kind of theatre much resembling "the theatre of cruelty" by Antonin Artaud, who proposed a return to magic rituals on the theatre scene. Ritual as a form of performance was an idea very dear to Birtwistle, nourished by his fondness for myth.

The composer as well as librettist were fond of some formal ideas. One of them was triplicity. Three acts, and each act has three scenes; three personages, and each has three embodiments. Such an accent on triplicity evidently has a philosophic basis (the expla-

${ }^{17}$ Electronic music for opera was designed with the help of IRCAM engineers Barry Andersen and Jean-Batiste Barrier. Details can be found in [10]. 
nation may be connected to the Orphism in Zinoviev's text ). The librettist considered triplicity to be the soil of European culture beginning from the pre-Christian era, and the main mechanism of the complex impact was the unconscious instead of rational cause and effect logic. As a result, a very special structure appears: ramified, labyrinthine, saturated with repetitions and recurrences. Such a structure provides plasticity of thinking and softens formalism. This plasticity is evident in some of Birtwistle's remarks in his talk with Fiona Maddock: "I have to be strict with the ideas in order to hang on to the essential, basic issue of what the piece about. These blocks of material play a game. They keep their identity. They fuse in some ways. In other ways they don't"18 [12, p. 45]. Mentioning the game (in this case a game, not a play) leads to the notion of a multiplicity of strategies.

One idea seems to exceed the others: the idea of death and going away as passing and loss. Multiple situations of Eurydice's death arise in different contexts: in the symbolic reality, in imagination, in the dream, and in real life. Where does this pessimistic attitude to Orpheus come from? The explanation given by J. Cross in his book on Orpheus is the following: "The commencement of work on The Mask of Orpheus coincided almost precisely with the start of economic decline of the West, and the instability and loss of confidence that ensued" [8, p. 137]. The scholar continues: "I think it is possible to see just how acutely Orpheus articulates the anxieties of a newly emerging post-industrial, post-imperial, post-modern age" [8, p. 137]. A new epoch generates new ways of seeing the world as structured and destructured at the same time. We observe texts with binary oppositions as well as ternary constructions: violence-lirism, love-hatred, male-female, past-present, real-imaginary, present-historical.

The vast tragic fatality expressed in Birtwistle's “The Mask of Orpheus" exhausted this topic for a while. It was staged in 1986, and the next attempt was 17 years later in the chamber cantata (song cycle) "26 Orpheus Elegies," written to the Sonnets to Orpheus by R. M. Rilke.

\section{Orpheus Elegies, for oboe, harp, and countertenor (2003-2004)}

The years between "The Mask of Orpheus" and "Elegies" belong to the most active creative period. Birtwistle wrote four operas - "Yan, tan, tethera" after Northern English myths, "Gawain" after the King Arthur legends, "The second Mrs. Kong," a pasticcio based on the King Kong story, and "The Last Supper," a contemporary retelling of the "Last Supper" legend, with English and Latin libretto by Robin Blaser - and large-scale orchestral pieces such as "Panic" for saxophone, "Exody" and "The Shadow of Night" for orchestra, and many chamber compositions. Text always was important for Birtwistle, but in the 1990 s the setting of poetry becomes especially notable: 4 Poems by Jaan Kaplinski, for soprano and 13 instruments (1991); 9 Settings of Celan (performed as a set or individually) for soprano, 2 clarinets, viola, violoncello, and contrabass (1989-1996); "Pulse Shadows" (the 9 Movements for string quartet interleaved with the 9 Settings of Celan) (1989-1996); 9 Settings of Lorine Niedecker, for soprano and instrument, not piano (1998-2000). After these cycles a "Rilke period" sets in: 26 Orpheus Elegies, for oboe, harp, and countertenor (2003-2004), Bogenstrich (Bow-stroke) (2006-2009) 28' for voice, cello, and piano. The

18 One more piece of evidence of the composer's working method: "I can't write movements. I've never written movements. I've written pieces, unless it's a song text then you stop at the end of the song. It's just a lot of bits stuck together, my music!" [12, p. 106]. 
turn to Rilke was obviously initiated by continuing attention to the Orpheus theme. Oddly enough Rilke was in the same way inspired by the Orpheus myth as was Birtwistle: in 1907 he wrote a poem "Orpheus. Eurydike. Hermes," and in 1922 "Orpheus Sonnets"19.

The composer commented on the beginning of the work: "What I wanted to do was to write an ambitious piece for oboe and harp. I started to write it, alongside reading the text. I suddenly realized that that the text had to have an existence within the thing but it couldn't be there all the time. I see oboe as being Orpheus, and his instrument the harp, and the countertenor is like the narration, it's all about music and the presence of music" [13, p. 9].

The oboe as personification of Orpheus links the "Sonnets" to previous compositions, e.g. the solo clarinet in the "Nenia" and "Linoi." The music reflects some ideas absent earlier: besides the usual motives of love, song, and lament, Rilke activates contemporary topics: the new era, machines, and the violent reality of the present. Rilke's texts are fragmentary, and this quality was attractive for the composer who tended towards combinatory thinking. As Birtwistle noted: "I wanted the text to be here in the way that you might say Debussy used the long poem L'Après Midi d'un Faune by Mallarmé. The music is the atmosphere that he has derived from his idea of what he thinks the poem is about. You can't deny the existence of the text. I put it at the end of each Elegy in the way that Debussy put them at the end of his Etudes" [14, p. 7 ${ }^{20}$.

The structure of "Elegies" has elements of aleatoricism: they have to be started with the first piece and ended by the nineteenth, but among pieces different orders are possible. Each Elegy has its inner diversity of manners, but it is not the surrealism which defines such a composition. Still, the relations of elements are nevertheless evident. In some ways Birtwistle returns to traditional topoi, for example, one of the elegies is based on the lament figure (ex. 4).

Birtwistle comments: "That one is about a death. It's like being struck, and then having less energy. The harp has the function of the death blows" [14, p. 7]. Explaining the whole idea, he wrote: "The pieces $\langle\ldots\rangle$ are like samples, they are not through composed, they are like fragments. There is something that Paul Klee describes called dividual and individual. We know what individual means, but dividual is not a word you'll find in a dictionary. Its Paul Klee's own word $\langle\ldots>$ it's very interesting. A wallpaper pattern is dividual because you can take a piece from it and it still retains its essential identity. You have a bottle of wine, the bottle is individual, the liquid in it is dividual because you can drink some of it and it's still the same wine, but the bottle itself, if you break the neck, is individual. So there are two elements which are completely opposite" [13, p. 11]. The "dividuality" of the cycle causes the approach to the form: it is akin to a true aleatoric as Boulez considered it.

The difference of Orpheus Elegies from the other pieces of the "Orpheus projects" lies in the form of presentation: as composer states, "the movements in the 'Orpheus Elegies' are like postcards with cryptic text" [13, p. 8] meaning that the composer even less than earlier sees the Orpheus story as a narrative. He is fond of fragmentary statements, and this fragmentarity becomes even a foundation for the form: changing places of the movements

${ }^{19}$ It s possible to see a latent form of the Rilke Sonnets idea before Birtwistle started the process of composing: in 1959 the poem by Robert Lowell "Orpheus, Euridice and Hermes" was published, which is a retelling of Rilke's verse [see: 3 , p. 342].

20 Birtwistle has mistaken Etudes for Preludes, which have textual commentaries in the end of the pieces. 

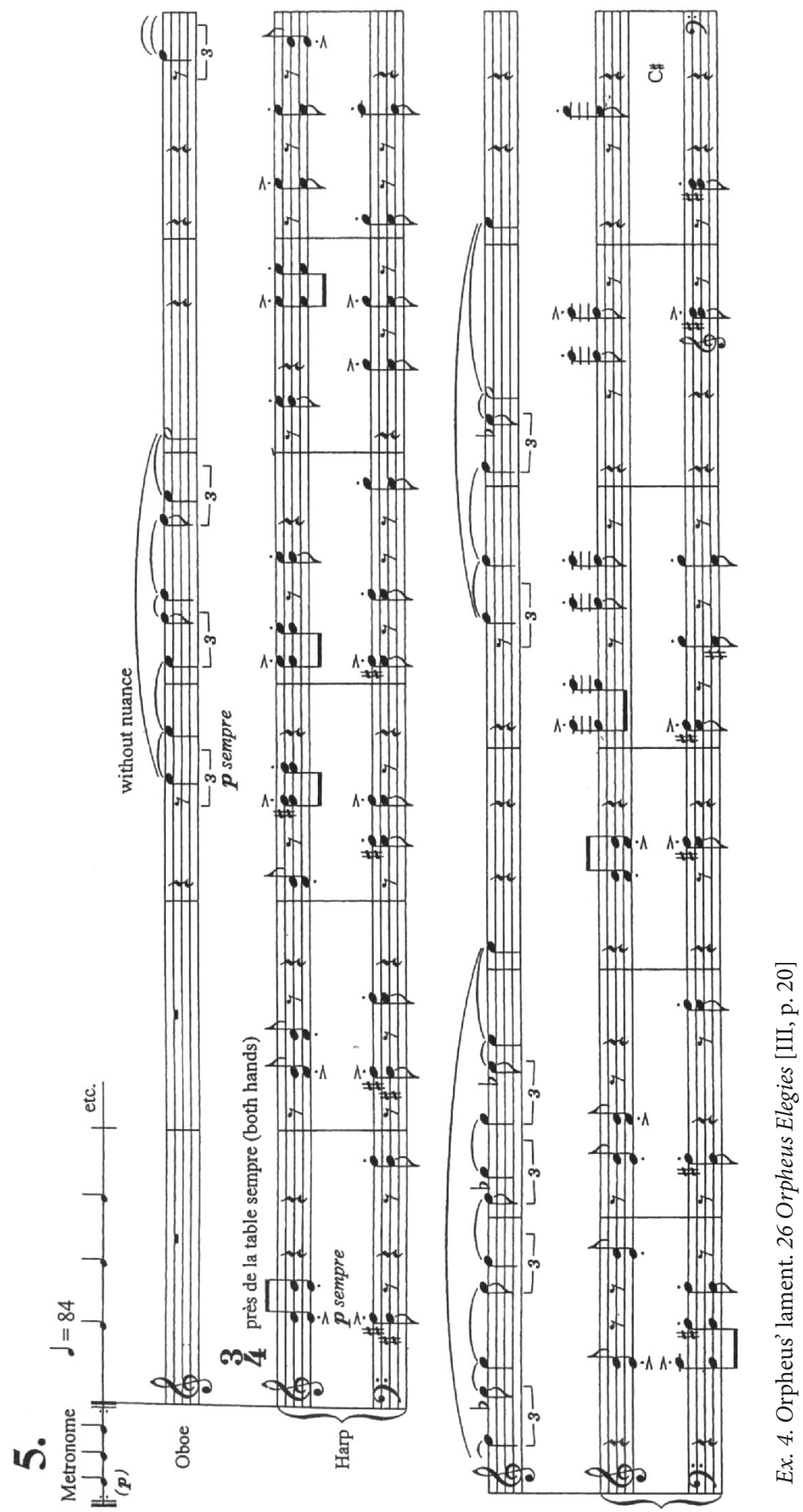
helps to establish a maze, a labyrinth, and in this case Orpheus Elegies open the path to the last opera by Birtwistle - to "Minotaur".

\section{Around Orpheus}

Now it is time to observe the compositions which form the periphery of Orpheus project. After "Nenia," Birtwistle wrote "Meridian" (1970-1971) ${ }^{21}$. At first glance it is not connected to the Orpheus project, but looking more closely we see some threads that link it to Orpheus. The text for the piece was taken from Christopher Logue's "The image of love" and lines from Sir Thomas Wyatt's "Blame not, my lute" and "My lute awake." The imagery of the text is highly abstract, and only some details and indirect indications point to the Orpheus myth. Scholars M. Hall and J. Cross explain the allegories of the text by its closeness to an interpretation of Orpheus story set by Boethius and Erigena. Among philosophers it is held that Orpheus' love was too physical. Birtwistle returned to Boethius late in his choir piece "On the Sheer Threshold of the Night." The point developed by Boethius is explained by M. Hall: "Had he (Orpheus. - T. T.) kept his eyes on the light of reason ahead of him all would have been well; but in turning to look back at Eurydice in the twilight of unreason he lost her" [5, p. 78]. This idea is developed in some Medieval sources: Orpheus is considered of worldly song and Eurydice as an image of divine mystery. The word "meridian" also has Orphean connections: Orpheus being in ward of Apollo is connected with the sun and Eurydice is twilight. Meridian is the time of midday when Orpheus sings his song and is farthest from Eurydice.

The text is rather sophisticated and obscure, but the music speaks for itself. The instrumentation is clearly pointing to "Nenia":

$\begin{array}{lll} & \text { Nenia } & \text { Meridian } \\ \text { Vocal } & \text { soprano } & \text { mezzo-soprano + choir } \\ \text { Wind } & \text { bass-clarinet, clarinet in B } & \text { 3 oboes, 3 clarinets, horn } \\ \text { String percussion } & \text { prepared piano } & \text { piano, 2 harps, cello } \\ \text { Percussion } & \text { crotales } & \text { two percussionists }\end{array}$

Birtwistle presents the key image of singing and playing, transmitting them into the realm of metaphysical love. Meridian is a love song; it is also, secondarily, "about" the nature of song and of creative activity. The musical axis of a piece is the duet of horn and cello; they are united by a central tone "e" supporting the musical construction. "Meridian" is seen as an axis between life and death, day and night, reason and intuition.

\section{“The Fields of Sorrow"22 (1972)}

This composition set the text by Latin author Ausonius as translated by Helen Waddell [15]. The source is the text of Aeneid where the wanderings of the shadows are depicted. As earlier, Birtwistle draws indirect images. Nobody names Orpheus or Eurydice,

${ }^{21}$ Meridian for mezzo-soprano, horn, cello, two 3-part choirs of sopranos, 3 oboes (doubling cor anglaise), 3 clarinets (doubling bass-clarinets), 2 harps, piano, and percussion (2 players).

22 "The Fields of Sorrow" for 2 sopranos, 8-part choir and instruments. 
but some details of the text point to Hades: those who wander through the fields with poppies in the dark evidently overstepped the limits of earthly existence. Poppies belong to the symbols of death, and this symbolism is expressive as an indication of a place of action. As in the previous piece, the text could be interpreted differently, but its realization is clear: Birtwistle uses for this new piece for musical ideas that are very much the same.

The overall configuration of instrumental and vocal performers is dispersed spatially, and this differentiates the entire setup from the previous piece. Two coordinates are of special importance: from left to right and from avant-scene into the back of scene. At the back of the platform, two solo sopranos wordlessly call to each other from the two corners. The next line from left to right is occupied by choir in the whole width of a platform. Ahead of the choir are the percussion instruments: two grand pianos and vibraphone make a tight group almost in the center of the configuration. On the foreground in a line are seated wind instruments (three bass-clarinets, three bassoons, horn, three cors anglaise, three flutes); and in the center in front of all them the conductor is placed (ex. 5).

No events are described, and the whole impression comes from the description of a paysage that is nothing but sorrowful. The mysterious actors are interpreted by Birtwistle as Orpheus and Eurydice who act as each other's echo (ex. 6).

The composer develops a very specific allusion to each other's calls: he tries to give us a wonderful picture of wandering through the mysterious landscape to the exit and to light, and the vivid detail is the play of the calls. The idea developed by Birtwistle is realistic: indeed, what should one do when making one's way out of a thick forest? He will from time to time call to his companion to make sure they did not lose each other. All this invisible dialog happens on the background of several layers of sound: the choir rings out the text like a tolled bell in the distance. This bell-like sound is supported by piano and the vibraphone, the bell-like instruments. All means of expression form a clear picture of journeying along the forest on the background of a somber tolling. And again

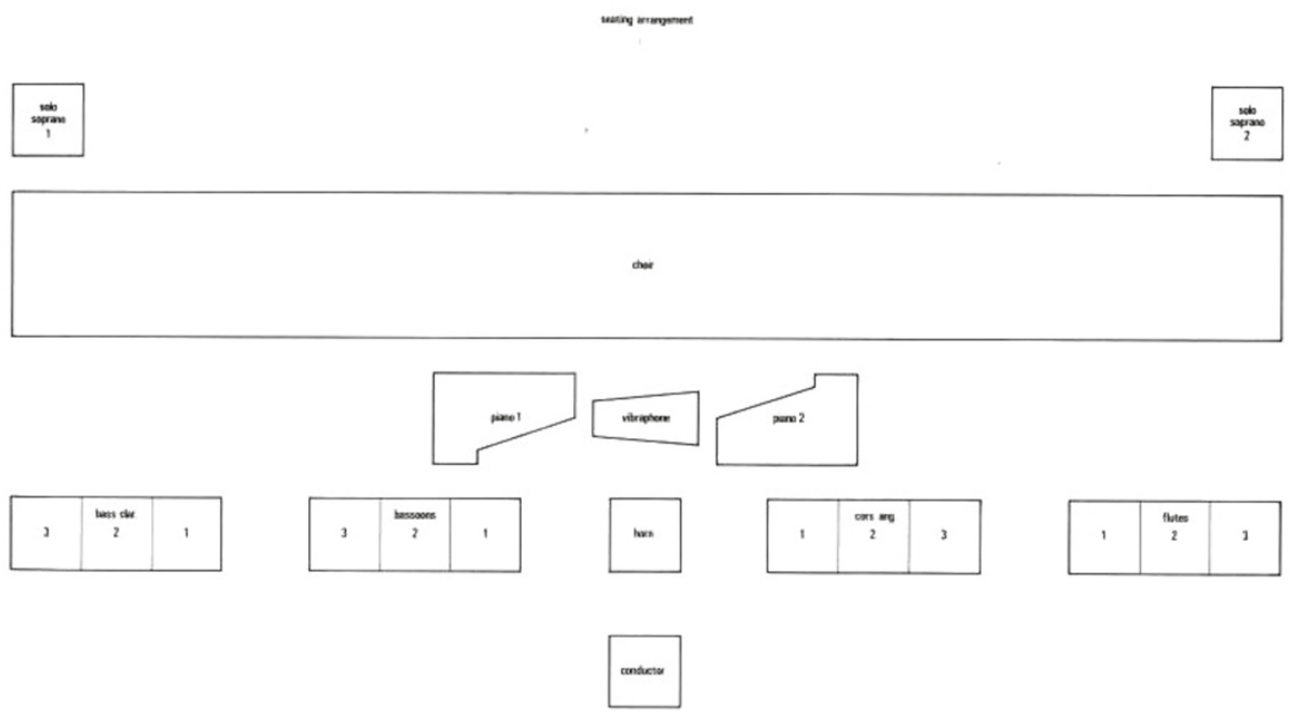

Ex. 5. Placing of the performers. "The Fields of sorrow" [IV, p. iii] 


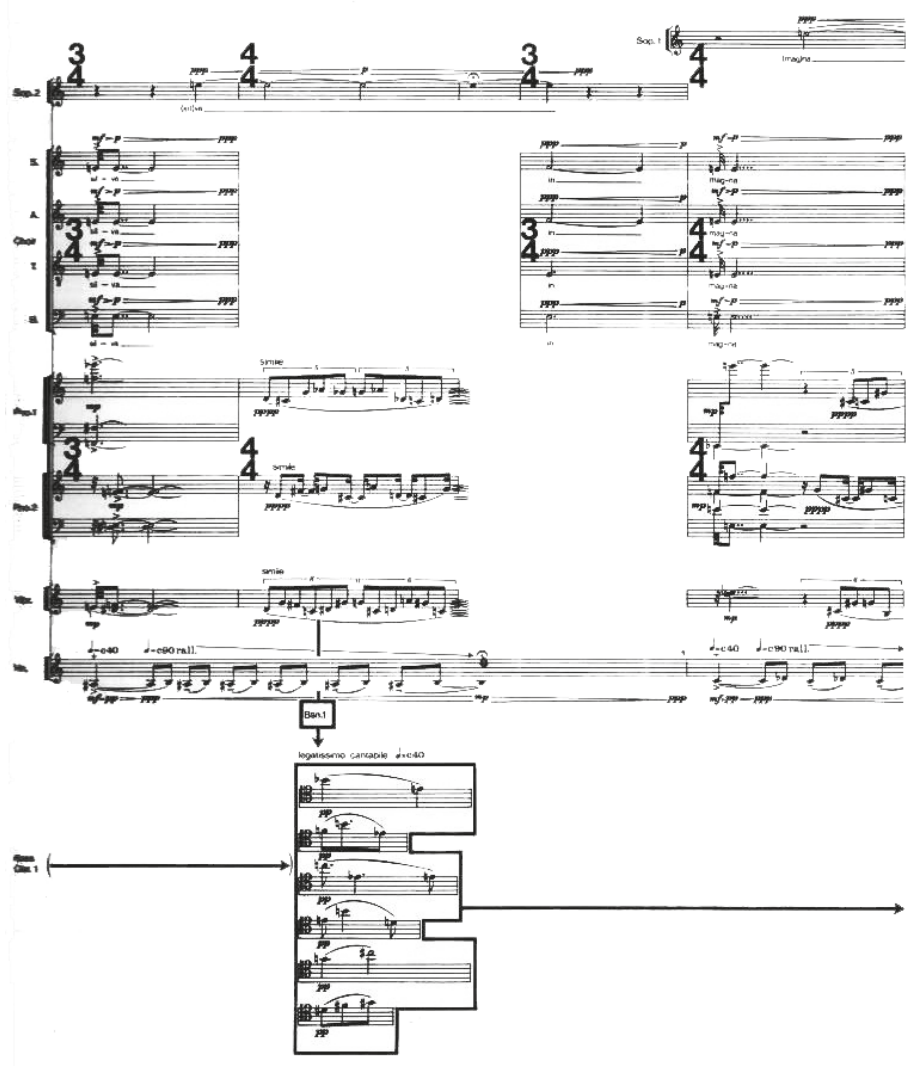

Ex. 6. Echo of the soloists. "The Fields of sorrow" [IV, p. 3]

the "e" is set as a central tone, as in "Meridian". The overall expression is somber and full of melancholy.

\section{"On the Sheer Threshold of the Night" \\ for 4 solo voices and 12-part choir (1980)}

For this text Birtwistle used Boethius' Stupet tergeminus novo (The Consolation of Philosophy), also contained in Helen Waddell's Medieval Latin Lyrics [15]. Birtwistle's setting is a madrigal, and its most distinguished feature is the placing of the singers. They are arranged in the arc, and in its center two singers are positioned: the counter-tenor and the tenor itself. The evident purpose of such two-voiced presentation of Orpheus is the Jungian concept of the anima: the placement of the singers clearly points to the two-sided nature of Orpheus. To the left of this pair the men are ranged, and the women are to the right. The men represent the ego (reason); the women represent anima (intuition). These two forces play against each other during the entire piece (ex. 7).

Seeing how thoroughly Birtwistle develops different aspects of the Orpheus story, we can propose a special purpose for this composition. The inner fight of Orpheus, his own hesitations and his central action - turning to Eurydice - what were they inspired by? Two sides are indicated in Orpheus' nature, two options are opened to him. The men (rea- 


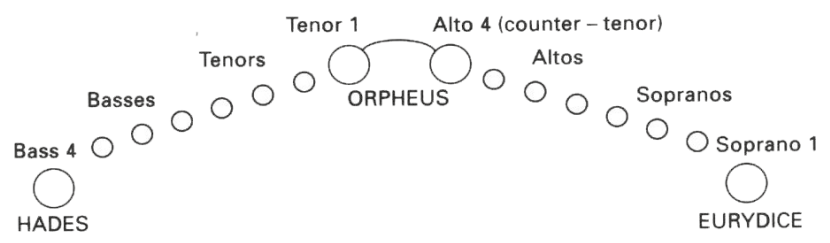

\footnotetext{
Commissioned by the Hessischer Rundfunk, Frankfurt. First performance at Hessischer Rundfunk by John Alldis Choir, conducted by John Alldis, 10th May 1980
}

Ex. 7. Placing of the performers. "On the Sheer Threshold of the Night" [V, p. iii]

son) and the women (intuition) sing throughout the piece against each other. But when the decision is made they merge: "Yet is not love his greater law? And who for lovers shall decree?" Losing his reason, Orpheus loses Eurydice.

The madrigal is cast in eight sections, with the first four introduced by Orpheus calling to Eurydice. At the climax of the work, when Orpheus makes his decision to set his face against reason and choose irrational love, the chorus is reconciled and the soloists are absorbed. The text switches from Latin to English: "On the sheer threshold of the night Orpheus saw Eurydice, looked, and destroyed her" [16].

The style is very elaborate: special attention is paid to sopranos who sing in a very high register. As almost all the text is a personal dialog of Hades and Orpheus, this kind of singing makes the impression of a "choir of shadows" with their immaterial and "unhuman" singing (ex. 8). The voice of Orpheus is divided in two, and this leads us to the interpretation of his personality as dualistic: his love for Eurydice is overwhelming and self-forgetful as far as he is risking to pay a visit to Hades, but it is also egoistic because of his unbearable desire to see her - and this leads to Eurydice's destruction. Possibly this may explain the structure of Orpheus' part: we often hear two lines that represent imprecise inversion of the same melodic line (ex. 9). 


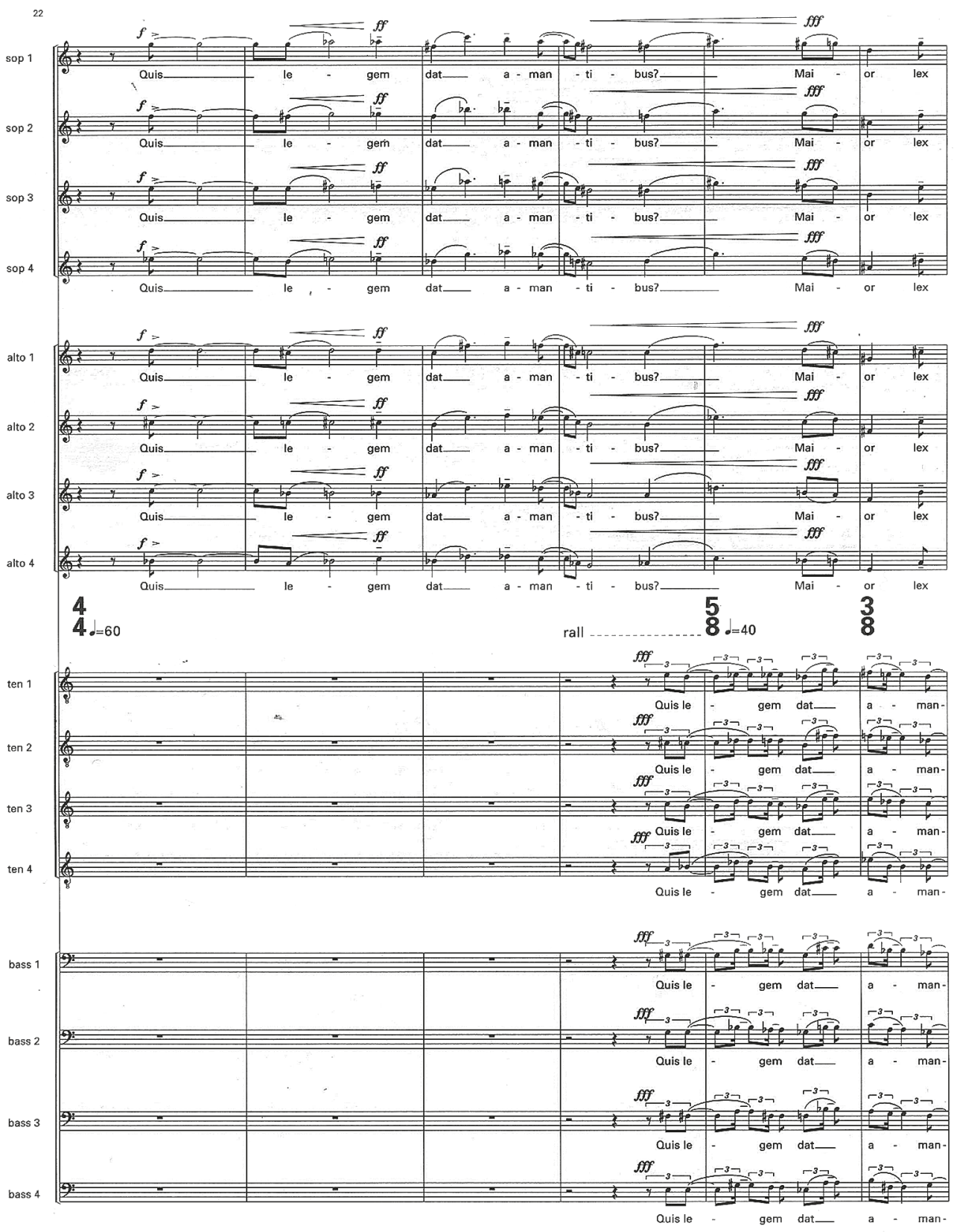

UE $16410 \mathrm{~L}$

Ex. 8. Eurydice's singing. "On the Sheer Threshold of the Night" [V, p. 12] 


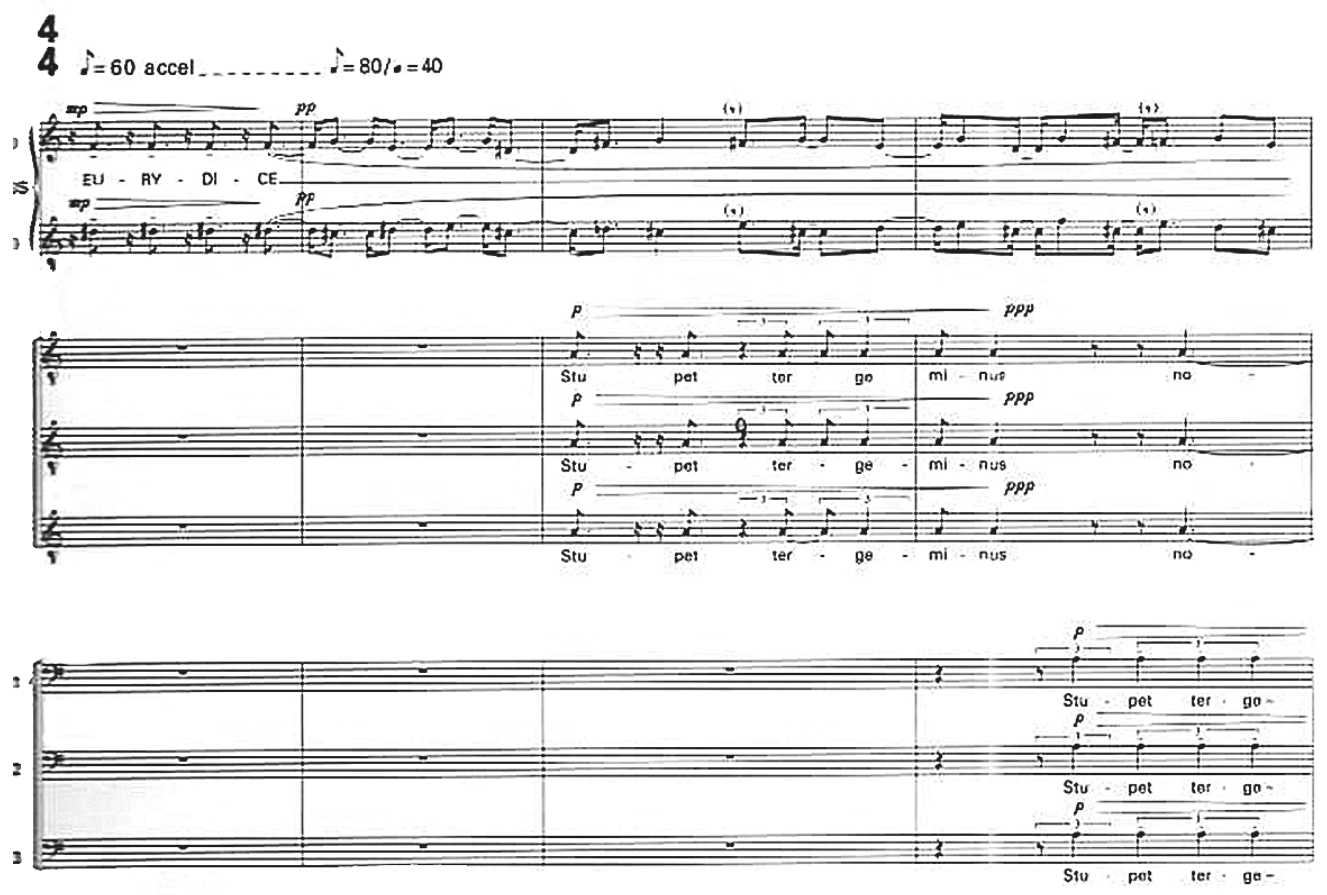

Ex. 9. Two voices of Orpheus. "On the Sheer Threshold of the Night" [V, p. 1]

\section{“The Corridor”, chamber opera (2008)}

"The Corridor" first appeared as a visual scenario in the course of productions of the National Theatre. Birtwistle was going to concentrate on "a single moment from the Orpheus story magnified, like a photographic blow-up" [3, p. 224]. This "magnified" moment was the point of the story when Orpheus turned to look at Eurydice and lost her. In "The Mask of Orpheus" Birtwistle includes the scene with its fatal turn, but it does not belong to the key scenes of the opera and is rather insignificant. In "The Corridor," the composer concentrates on this turn, on the very second when the irreversible harm happens. Birtwistle also wanted to use the possibility to turn Eurydice into a puppet; he felt, it was not satisfactorily used in the previous opera. He explains: "The whole idea of close-up that you get in cinema has no equivalent in opera: you can't have an opera about someone having a cup of tea. But there's a moment in the Orpheus legend - Eurydice's demise, when she is condemned to remain in hell - that seemed to me to hold an interesting idea, something you could present in close-up. That moment became the scale of the whole piece" [17].

Nine sections of this chamber opera represent nine lamentations of Orpheus, accompanied by a harp on the scene. The successions of events include: Orpheus turns, at which moment Eurydice immediately begins to drift apart, returning to Hades until her contour disappears in the dark. During her journey back she meets Shadows-those who died and passed to the Underworld-represented by a quintet of musicians sitting on the 
scene. The uintet consists of flute, clarinet, violin, viola, and cello. The scene represents a Corridor between the Underworld and the outer world, between the dark and the light. Two performers (a woman and a man) act differently according to the function they perform. The woman is in character as Euridice and the narrator, and her function is defined by her place in the scene: when on the scene she plays narrator, when in the hall she plays Euridice. Nine sections are punctuated by the return to the same moment. Formal divisions are emphasized by different vocal styles: singing lament, spoken dialogs. The drama after the turning is explained by librettist D. Harsent; "Orpheus wants Eurydice back but does she want to go? How is it going to be for her? She isn't certain that the land of the living is the place to be" [17, p. 241]. The gradual disintegration of Eurydice includes her ability to speak, and she sings fragmented text, unable to return to mortal life. As Birtwistle remarked of Eurydice: "As she travels, she's deteriorating, disintegrating as she goes deeper. The music also disintegrates as she goes down. To do this, I create music for her that repeats, and as it repeats, it fractures and slows down, like a clock winding down" [17, p. 347]. The death comes as a slowly unwinding mechanism. As A. Whittall says, "it's a journey ending in death" [18, p. 25].

\section{Conclusion}

Today, Harrison Birtwistle is over 80 and his list of compositions is long. His main ideas became explicit during the course of his compositional career, and the myth of Orpheus became the key feature of his legacy. Birtwistle's relations with the Orpheus myth are quite special because he created a whole series of compositions following his own inner "map" of the myth; we can imagine a kind of network where every tiny event, every detail may be considered as a starting point for further composer's reflections. Today the composer explains this "map" from the point of view of his compositional method: "I do a lot of things that spring from one idea. It goes through a lot of different processes, which I forget and re-invent as I need them <... ${ }^{\prime}[12$, p. 5].

The complex of ideas characteristic for the Orpheus project is wide. Time is one of the essential ingredients of the Orpheus legend. Its irreversibility (Orpheus will never return his beloved) is a source of never-ending melancholy, also fed by senses of pity and loss. The composer is fully aware of his source of inspiration: "I have to apologize in what you are about to hear because they are an aspect of my personality that is to do with my melancholia $\langle\ldots\rangle$. And so, consequently, when you hear the songs of mine, you see a personality of what I would call melancholia. In England we have a very potent piece of melancholia in the Elizabethan music of Dowland, which I'm very attracted to" [14, p. 3].

When Birtwistle talks about Dowland, he refers mostly to his "Corridor" opera. This opera is a companion piece to the composition "Semper Dowland, Semper Dolens: Theatre of Melancholy" (2009). In this composition, six pieces by Dowland for voice and lute arranged for tenor and harp are mixed with instrumental arrangements of Seven Pavans by Dowland. The songs are organized into a whole that narrates indecency, treason, and loss of love. All these themes continue to develop in "Corridor."

Theatre of Melancholy -isn't it the right name for a work by Birtwistle? Patrick Wright, Professor of Literature and Visual and Material Culture at King's College, University of London, wrote: "We also talked a lot about Harry's long-standing interest in Dürer's Melencolia I - an engraving which has long preoccupied him for its enigmatic balance of 
contraries. It depicts a seated angel, winged but immobile and surely far too heavy to fly $\langle\ldots\rangle$ Everything suggests movement and activity, but at the same time everything is still. Stasis in mobility, and vise versa, as Gunter Grass described it in From the Diary of a Snail, one of the many texts Harry has read in his exploration of this theme $\langle\ldots>$ He takes sense of repetition, circularity, disconnection and suspension - which are all long-standing characteristics of melancholy thought - of 'melancholising' as practiced by Burton (The Anatomy of Melancholy, 1621) and of course of John Dowland and Shakespeare too <... " [12, p. 96-7]. Jonathan Cross states almost the same: "Birtwistle's music has always existed in a world of shadows. The tendency towards the melancholic announced itself most explicitly in Melencolia I for solo clarinet, harp and strings of 1976, taking Albrecht Dürer's famous engraving of the same name (1514) as its starting point and mediated via Günter Grass's essay on the picture" [19, p. 293].

Reversing time lets us fix the images of melancholy in Birtwistle's compositions. "Sonnets to Orpheus" demonstrate fragments of laments, reflections on the death of Euridice; "On the Sheer Threshold of the Night" depicts the cruelty of the moment when Orpheus lost Eurydice forever and the duality of Orpheus's consciousness and unconscious thoughts. "The Fields of Sorrow" is a mournful landscape, the background to the whole tragedy, the point of contemplation. "The Meridian," the most refined reflection on the allegory of Orpheus, actualizes the context of the legend and its metaphysical aspects. "Nenia" and "Linoi", both threnodies, incorporate details of ritual and overall sense of mystic force lying in the center of the story. The biggest monument to melancholy is the opera "The Mask of Orpheus." In its frenzy we find an extreme level of open despair and evidence is the series of iterated events: several deaths of Orpheus, a number of Eurydice's deaths, extreme attention to the themes of memory, loss and love.

Birtwistle admits that melancholy came to the fore more than he intended. When asked why, he said simply: "There are certain things I don't have to answer. Are there jokes in mythology? I don't see it as my role to do humour" [16].

His position is widely acknowledged as an outstanding master who is famous all over Europe [20] and his conviction in music's great spiritual role won him respect of colleagues and love of listeners.

\section{References}

1. Cross, Jonathan. “The Mask of Orpheus”. In Birtwistle, Harrison. The Mask of Orpheus. BBC Singers, BBC Symphony Orchestra. Andrew Davis and Martyn Brabbins. Recorded April 11-12, 1996. NMC Recordings Ltd., 1997.

2. Adlington, Robert. The Music of Harrison Birtwistle. $3^{\text {rd }}$ ed. Cambridge: Cambridge University Press, 2014.

3. Beard, David. Harrison Birtwistle's Operas and Music Theatre. Cambridge: Cambridge University Press, 2017.

4. Cross, Jonathan. Harrison Birtwistle: Man, Mind, Music. Ithaka; New York: Cornell University Press, 2000.

5. Hall, Michael. Harrison Birtwistle. London: Robson books, 1984.

6. Hall, Michael. Harrison Birtwistle in recent years. London: Robson books, 1998.

7. "Harrison Birtwistle Quotes". Accessed January 31, 2019. https://www.idlehearts.com/quotes/author/ harrison-birtwistle.

8. Cross, Jonathan. Harrison Birtwistle: The Mask of Orpheus. Farnham: Ashgate Publishing Limited, 2009.

9. “Peter Zinovieff”. Accessed January 31, 2019. https://en.wikipedia.org/wiki/Peter_Zinovieff. 
10. Hall, Thomas. "Before the Mask: Birtwistle's Electronic Music Collaborations with Peter Zinovieff". In Harrison Birtwistle studies, edited by David Beard, Kenneth Gloag and Nicholas Jones, 63-94. Cambridge: Cambridge University Press, 2015.

11. The Mask of Orpheus. An Opera in three acts. Libretto and Scenario: Peter Zinoviev. Music: Harrison Birtwistle. Vienna: Universal Edition, 1986

12. Maddocks, Fiona, and Harrison Birtwistle. Harrison Birtwistle. Wild tracks. A conversation diary with Fiona Maddocks. London: Faber \& Faber, 2014.

13. "Harrison Birtwistle interviewed by Stephan Meier". In Birtwistle, Harrison. Orpheus Elegies; Three Bach Arias. Melinda Maxwell, Helen Tunstall, Andrew Watts, Claire Seaton, William Stafford, Tom Verity, Ben Fullbrook. Recorded August 28-29, September 25, 2008. Oboe Classics CC2020, 2008.

14. Birtwistle, Harrison. Songs 1970-2006. Alice Rossi, Das Neue Ensemble, Stefan Asbury, Kuss Quartet, Soloists of the HMTMN, Theater und Medien Hannover. Recorded October 25, 2014. Toccata Classics TOCC0281, 2015.

15. Waddell, Helen, transl. Medieval Latin Lyrics. London: Constable \& Co., 1929.

16. Clements, Andrew. "Work introduction". Sir Harrison Birtwistle: On the Sheer Threshold of the Nigh. Accessed January 31, 2019. https://www.universaledition.com/composers-and-works/sir-harrison-birtwistle-64/works/on-the-sheer-threshold-of-the-night-3960.

17. Clark, Andrew. "Interview: Sir Harrison Birtwistle on the Joy of Music". Financial Times, March 6, 2009. Accessed January 31, 2019. http://www.ft.com/cms/s/2/5ccaa0d0-09dd-11de-add8-0000779fd2ac.html.

18. Whittall, Arnold. "Let it Drift': Birtwistle's Late-modernist Dramas". In Harrison Birtwistle studies, edited by David Beard, Kenneth Gloag and Nicholas Jones, 1-25. Cambridge: Cambridge University Press, 2015.

19. Cross, Jonathan. "Of Shadows and Mirrors: Reflections on Birtwistle in the New Millennium". In Harrison Birtwistle studies, edited by David Beard, Kenneth Gloag and Nicholas Jones, 293-302. Cambridge: Cambridge University Press, 2015.

20. Delaere, Mark. "Gigue Machine and Other Gigs: Birtwistle in Europe and Beyond". In Harrison Birtwistle studies, edited by David Beard, Kenneth Gloag and Nicholas Jones, 264-92. Cambridge: Cambridge University Press, 2015.

\section{Music Editions}

I. Birtwistle, Harrison. Nenia: The Death of Orpheus. London: Universal Edition, 1970 .

II. Birtwistle, Harrison. 26 Orpheus Elegies. London: Boosey and Hawkes, 2005.

III. Birtwistle, Harrison. The Fields of Sorrow. London: Universal Edition, 1973.

IV. Birtwistle, Harrison. On the Sheer Threshold of the Night. London: Universal Edition, 1980.

\section{Appendix I}

"Nenia: The Death of Orpheus" (Narrator's Part)

Orpheus, on the top of the hill; sings.

His music, which once moved the shades to tears,

Now moves rocks.

Orpheus has turned from women; rejected men;

Since losing twice his love Euridice.

She, snake-stung, slipped back across this river,

(A crazy and, some say, a pre-determined whim)

But what once happened can happen once more,

So Orpheus sings and plays to move his father Jove,

To some sort of repentance.

Singing and dreaming of Euridice,

Whom he sees as a shadow,

And questions to himself her existence,

He turns again and again, 
Re-enacting the moment when he last saw her,

Hoping to catch Euridice in time.

The snarls of venomous jealous women awoke Orpheus.

They had surrounded him carrying clubs and stones

They attacked him and killed him

Orpheus was torn apart limb from torso, bones from flesh.

Blood.

All the world and skies mourned and despaired his death.

The women were turned to rocks and the rivers moaned.

As his remains were carried on their surface to the sea.

Earthquakes, thunder, floods and darkness.

As is customary.

And this was the passing of Orpheus.

Except for his skull, which, cast up, much later,

On a distant stony shore, was stung,

Or nearly so, by another snake

\section{Appendix 2}

\section{Introduction to a published version of libretto by $\mathrm{P}$. Zinoviev}

The Mask of Orpheus is a lyric tragedy in three acts.

The use of the word Mask should suggest a slight connection with English Elizabethan masque which combined music, dance, poetry, scenic decoration and pageantry to express mythological and allegorical subjects.

The libretto is written in both short and a full form. These are, perforce, somewhat complex because the work is not linear, with parallel strands of lyrics, music and visual events. A conventional libretto is inappropriate. Sequentially the words do not determine the play. A different dramatic interpretation based on the music and words will be incoherent. This is in contrast with most masques (where there was only the loosest connection between the allegorical theme, the recitations and dances) and most operas where the action, words and music all combine at the same point to emphasize the story.

In the Mask of Orpheus all aspects are connected by a large scale and detailed logic derived from what is guessed about Orphism.

Orpheus was recognized in ancient Greece as a living symbol that marked the birth of theology, science and art. Plato and Pythagoras were Orphics. Orphism fathered many of the beliefs of the Christian church. Besides this rich religious and philosophical inheritance there is a great wealth of Orphic legend and mythology from Greek pre-history. Many of these myths have been used in poetry and music from the earliest times.

The present work tends to the Aristotelian view that Orpheus did not exist as an individual but is a collective inheritance. This enables any aspect of the diverse mythology to be treated as equally probable.

Plato, in the Timaeus, divides the Soul of the World according to numbers, binds it by analogies and harmonic ratios, and inserts the primary principles of geometric figures. This Orphic principle is followed in the Mask of Orpheus as a method of design. Therefor in the words and action, each gesture, adjective and suggestion is purposefully placed. Similarly in the music each event from a pause to a major ensemble is tied into specific overall plan. A successful production should allow the unfolding and clarification of this plan to be clear and the symbiosis between what is seen and heard to become obvious.

Two main themes mould The Mask of Orpheus. The first is a slow evolution from the birth of music to its final destruction. 
The second divides the work into three acts (and, less strongly, into 9 scenes) which in total are of three hours duration. Each act is dominated by a further structure which determines the exact timings of the dramatic events, words and music.

The plot is exciting. Parts of it are well known. It deals with the love story of Orpheus and Euridice, and their violent deaths. These are described later.

The Orphic inheritance is used to express a dialogue between the lyrical and violent, love and hate, man and woman, the future and the past and the real and imaginary. These are manifested in the development of contrasting myths of Orpheus and in his transformations and transition from a man into a god.

Orpheus designated the Supreme Cause, Chronus or Time. There is some evidence that this was divided into three: "unending time", "manifested time", and "unborn time". In The Mask of Orpheus time is expressed through memory as echoes and distortions. The music, words and actions repeat previous sections and anticipate future ones. Echoes and pre-echoes persist throughout. The first words are almost the same as the last. This system allows the same event to be presented from different aspects at different times or even simultaneously.

The Orphic symbological method divided things into three. These triads were held together by the general principle of "wholeness"; whence the Christian adaptation into "three in one and one in three". Each significant event in the Mask of Orpheus is given a specific name, whether it is a major song or a dramatic event. These 126 events are divided into 42 groups of 3 . The names used are part of the choreography: they are suggestive as to style. They are marked in prominent boxes in both the score and the text.

Such transitions and evolutions determine that the principle characters (Orpheus, Euridice and Arestaeus) each have three roles: two singing and one acting. This allow a gradual and overlapping change from man to myth or, as is suggested in the libretto, from Singer to Mime to Puppet.

Other characters include a Troupe of Ceremony and an acting ensemble which periodically interrupt the work at moments of greatest and least tension.

Several devices are used to alter the emphasis of what is seen and heard such as silence, pauses, freezes, interruptions and signals. They are used to emphasize the dramatic and metaphysical tensions. A visual separation is inferred as "above" and "below", "left" and "right", "behind" and "in front". Each character is assigned a specific "side". Such balancing in mythology is traditional. What is high has a counterpart in what is low. The past is contained in the future. The clear is contrasted with the cloudy.

A number of stage instructions are given which, while seeming very precise, are allegorical. For example "total darkness" or "disappearance" should not be taken literally. Suggestions as to the production, the sets, the characterization in the illustrations and instructions are offered in the same spirit.

Reference is made to a movable, variable sun (to represent Apollo), to sets of black rocks, snakes, a Golden Carriage of Mirrors (to allow transformation from one embodiment to another), skulls, dolls and other images. These are symbols, hints, and clues and are not production or design instructions. Substitution might be logical provided the tokens remain consistent and derivative.

The production of The Mask of Orpheus need not be lavish. Contrasts pf scale, time and perspective must be maintained.

The first act is dominated by Ceremony.

The second act is controlled by an imaginary construction of arches.

The third act is determined by the movement of the tide on a beach.

Much of the last act is written in an invented language.

The Appendices describe these structures and derivations.

Plato, in "Epinomis" wrote: "I confidently assert, both in jest and in all seriousness, that such a play will, from the many senses it has now, possess a uniform body, and so become one from many and will give happiness". This is the difficult task we have given to the producer and designer of our piece. 
Appendix 3

\author{
"The Fields of Sorrow" \\ Errantes silve in magna et sub luce maligna \\ Inter harundianeasque comas gravidunque papaver \\ Et tacitus sine labe lacos, sine murmure rivos, \\ Quorum per ripas nebuloso lumine marcent \\ Fieti, olim regum et puerorum, flores \\ Ausonius
}

\title{
Appendix 4
}

\section{"On the Threshold of the Night"}

Stupet tergeminus novo

Captus carmine ianitor,

Quae sontes agitant metu

Ultrices scelerum deae

Iam maestae lacrimis madent.

Non ixionium caput

Velox prae cipitat rota,

Et longa site perditus

Spernit flumina Tantalus.

Vultur dum satur est modis,

Non trahit Tityi iecur.

Tandem 'vincimur' arbiter

Umbrarum miserans ait:

'donamus comitem viro

emptam carmine coniugem.

Sed lex dona coerceat,

$\mathrm{Ne}$, dum Tartara liquerit,

Fas sit lumina flectere.

Quis legem dat amantibus?

Maior lex amor est sibi.

Heu noctis prope terminus

Orpheus Eurydicen suam

Vidit perdidit occidit.

Vos haec fabula respicit

Quicumque in superum diem

Mentem ducere quaeritis;

Nam qui Tartareum in specus

Victus lumina flexerit,

Quidquid praecipuum trahit

Perdit, dum videt infernos.

Boethius

Author's information:

Tatiana V. Tsaregradskaya - Dr. Habil., Professor; tania-59@mail.ru 